\title{
DMU40 MEGMUNKÁLÓ KÖZPONT VIZSGÁLATA II. VÉGES SZABADSÁGFOKÚ DINAMIKAI MODELL ANALITIKUS VIZSGÁLATA
}

\author{
Kiss Róbert \\ tervezömérnök, Diehl Aviation Hungary Kft. \\ 4300 Nyirbátor, Ipari Park utca 9, e-mail: robert.kiss9405@gmail.com \\ Szilágyi Attila \\ egyetemi docens, Miskolci Egyetem, Szerszámgépészeti és Mechatronikai Intézet, \\ Szerszámgépek Intézeti Tanszéke \\ 3515 Miskolc, Miskolc-Egyetemváros, e-mail: szilagyi.attila@uni-miskolc.hu
}

\begin{abstract}
Absztrakt
Jelen cikk egy hosszabb kutató-elemzö munka része, ugyanis az elvégzett munka föbb pontjain keresztül vázolja fel a vizsgált tématerületnek és az alkalmazott módszernek megfelelöen a vizsgálat során kapott eredményeket, következtetéseket. A kutatás központi témája a szerszámgépek dinamikai merevsége, illetve meghatározásának különféle módszerei. Az egyik ilyen gyakran alkalmazott eljárás a modálanalízis, amelyet elsöként analitikus eszközökkel igyekszünk végrehajtani. Cikkünkben egy ilyen vizsgálatot mutatunk be konkrét gyakorlati példán keresztül.
\end{abstract}

Kulcsszavak: analitikus módszer, dinamikai merevség, modálanalízis, sajátfrekvencia, VEM

\section{Abstract}

This article is part of a longer research-analytical work, because it outlines the results and conclusions of the study according to the main topic of the research and the applied method. The central theme of the research is the dynamic stiffness of machine tools and the various methods for their determination. The first such (finite element) method is modal analysis, which allows for an analytical test. The purpose of this article is to approach this study from the practical side through a specific example.

Keywords: analytical method, dynamic stiffness, modal analysis, natural frequency, FEM

\section{Bevezetés}

A vizsgálat során a DMU40 típusú CNC megmunkáló központ mechanikai-, és matematikai modelljének a minél pontosabb felállítása volt az elsődleges cél, a minél valósághübb eredmények elérése érdekében. Célunk a berendezés dinamikai merevségének analitikus módon történő becslése. A megmunkálógépek a szerkezeti elemek rugalmassága, valamint a fellépő gerjesztések miatt mindig rezgő rendszert alkotnak. Első közelítésben a vizsgálat tárgyát képező szerszámgép egy többszabadságfokú, csillapított, lineáris, gerjesztett rezgő rendszernek tekinthető [1,2]. A matematikai modell ezt, illetve a rezgéstani modellt egyaránt alapul veszi.

A mechanikai modell (1. ábra) előállítását követően írható fel a matematikai modell egy differenciálegyenlet-rendszer formájában, amelynek megoldása szolgáltatja az egyes részegységek 
(gépállvány, x-szán, y-szán, z-szán) különböző irányoknak megfelelő deformációját az idő függvényében (elmozdulás-idő diagramok).

A dinamikai merevséget alapvetően a következő tényezők befolyásolják: a statikus merevség, a lengést gerjesztő frekvencia, a sajátfrekvencia és a Lehr-féle csillapítás.

Mivel a megmunkálás során az alkatrészek méretpontossága, alakhűsége, valamint a felületi érdesség nagysága egyaránt fontos szempont, ráadásul ezeket jelentősen befolyásolják a rezgések, így elsősorban a fent már említett sajátfrekvencia helyeket célszerủ meghatározni, és ezek ismeretében érhető el jelentős mértékü javulás a megmunkálás pontossága terén.

\section{Mechanikai modell}

Az 1. ábra a Szerszámgépek Intézeti Tanszékének mühelycsarnokában található, a vizsgálat alapjául szolgáló 5-tengelyes CNC vezérléssel ellátott megmunkáló központ, burkolat nélküli katalógusképét állítja párhuzamba ugyanezen gép mechanikai modelljével. A rezgéstani modellen a négy fö építőegység mellett az építőegységeket összekötő sínes golyós kocsi és golyósorsó-anya rendszerek láthatók, amelyeket rugókkal és csillapításokkal helyettesítettünk. Majd katalógusadatok alapján ezek a rugómerevség értékek, valamint csillapítási tényezők meghatározhatóvá váltak.

A gép struktúra-egyenlete:

$$
A_{I} O_{f}(s, 4) X(s, 1) Y(s, 2) Z(m, 1) R_{y}(s, 3) R_{z}(m, 2)
$$
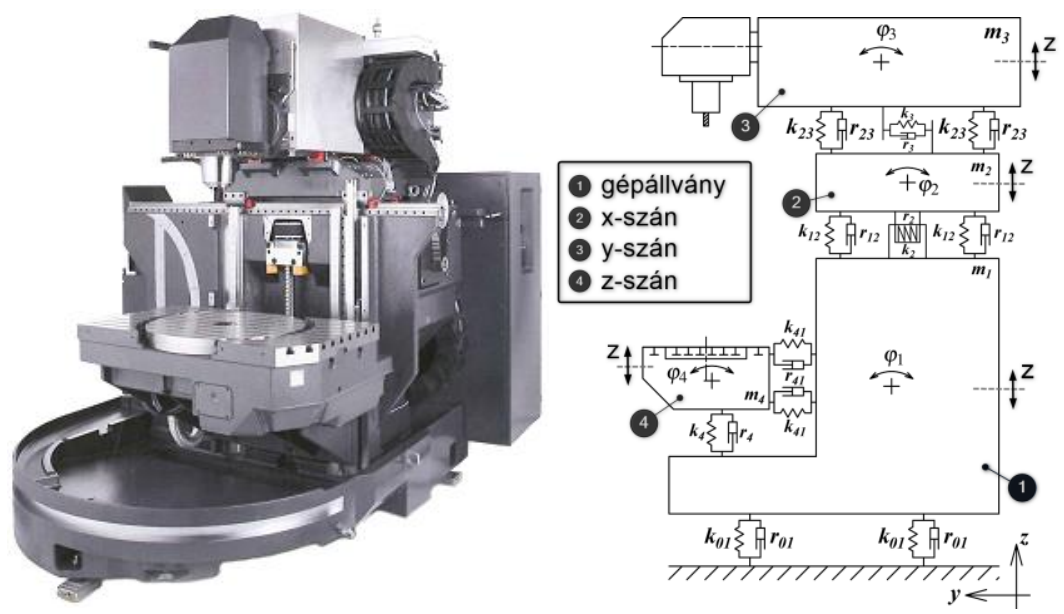

1. ábra. DMU40 megmunkáló központ katalógusképe és rezgéstani modellje

\section{Matematikai modell}

A fenti mechanikai modell (1. ábra) segítségével a rendszer mozgásegyenlete írható fel a másodfajú Lagrange-egyenletek segítségével [3]. Ezáltal egyaránt figyelembe vehetők a lineáris elmozdulások és a szögelfordulások is. Csillapítás figyelembevételével az alapösszefüggés az alábbi formában írható fel: 


$$
\frac{d}{d t}\left(\frac{\partial \alpha}{\partial \dot{q}_{i}}\right)-\frac{\partial \alpha}{\partial q_{i}}+\frac{\partial Q_{r}}{\partial \dot{q}_{i}}=Q_{f}
$$

ahol az $i$ index az aktuális általános koordináta sorszáma, amely esetünkben $i=1 \ldots 4$. A (2)-ben szereplő Lagrange-függvényt felírva, a fenti összefüggésben szereplö matematikai müveleteket elvégezve a következő (3) differenciálegyenlet-rendszert kapjuk, melyben a $z_{i}, \varphi_{i}$ koordináták rendre az elmozdulásokat és szögelfordulásokat jelölik.

$$
\begin{aligned}
& \ddot{z}_{1}=\frac{1}{m_{1}}\left[-\frac{\mathrm{z}_{1}}{c_{01}}-\frac{\mathrm{z}_{1}-\mathrm{z}_{2}}{c_{12}}-\frac{\mathrm{z}_{1}-\mathrm{z}_{4}}{c_{41}}-\frac{\left(l_{12}-l_{11}\right) \varphi_{1}}{2 c_{01}}-\frac{\left(l_{21}-l_{22}\right) \varphi_{2}}{2 c_{12}}+\frac{\left(l_{42}-l_{41}\right) \varphi_{4}}{2 c_{41}}\right] \\
& \ddot{\varphi}_{1}=\frac{1}{J_{1}}\left[-\frac{\left(l_{12}-l_{11}\right) \mathrm{z}_{1}}{2 c_{01}}-\frac{\left(l_{12}^{2}+l_{11}^{2}\right) \varphi_{1}}{2 c_{01}}\right] \\
& \ddot{z}_{2}=\frac{1}{m_{2}}\left[-\frac{\mathrm{z}_{2}-\mathrm{z}_{3}}{c_{23}}-\frac{\mathrm{z}_{2}-\mathrm{z}_{1}}{c_{12}}-\frac{\left(l_{31}-l_{32}\right) \varphi_{3}}{2 c_{23}}-\frac{\left(l_{22}-l_{21}\right) \varphi_{2}}{2 c_{12}}\right] \\
& \ddot{\varphi}_{2}=\frac{1}{J_{2}}\left[-\frac{\left(l_{21}-l_{22}\right) \mathrm{z}_{1}}{2 c_{12}}-\frac{\left(l_{22}-l_{21}\right) \mathrm{z}_{2}}{2 c_{12}}-\frac{\left(l_{21}^{2}+l_{22}^{2}\right) \varphi_{2}}{2 c_{12}}\right] \\
& \ddot{\mathrm{z}}_{3}=\frac{F_{g}}{m_{3}}+\frac{1}{m_{3}}\left[-\frac{\mathrm{z}_{3}-\mathrm{z}_{2}}{c_{23}}-\frac{\left(l_{32}-l_{31}\right) \varphi_{3}}{2 c_{23}}\right] \\
& \ddot{\varphi}_{3}=\frac{1}{J_{3}}\left[-\frac{\left(l_{31}-l_{32}\right) \mathrm{z}_{2}}{2 c_{23}}-\frac{\left(l_{32}-l_{31}\right) \mathrm{z}_{3}}{2 c_{23}}-\frac{\left(l_{31}^{2}+l_{32}^{2}\right) \varphi_{3}}{2 c_{23}}\right] \\
& \ddot{\mathrm{z}}_{4}=\frac{1}{m_{4}}\left[-\frac{\mathrm{z}_{4}-\mathrm{z}_{1}}{c_{41}}-\frac{\left(l_{42}-l_{41}\right) \varphi_{4}}{2 c_{41}}\right] \\
& \ddot{\varphi}_{4}=\frac{1}{J_{4}}\left[-\frac{\left(l_{42}-l_{41}\right) \mathrm{z}_{4}}{2 c_{41}}+\frac{\left(l_{42}-l_{41}\right) \mathrm{z}_{1}}{2 c_{41}}-\frac{\left(l_{42}^{2}+l_{41}^{2}\right) \varphi_{4}}{2 c_{41}}\right]
\end{aligned}
$$

A (3) DE-rendszert a Maple nevü matematikai szoftver segítségével, a Runge-Kutta módszert felhasználva oldottuk meg. A 2. ábrán vázolt diagramon a z-irányú elmozdulás mértéke látszik az egyes részegységekre vonatkozóan, a (3) DE-rendszerrel leírt mechanikai rendszerre. Csillapítatlan esetben a tömegek harmonikus oszcilláló mozgása tapasztalható, míg csillapított esetben (2. ábra) a csillapítás elnyeli az energiát, ami miatt a rendszer rezgése egy bizonyos idő után elhal.

A maximális kitérés az y-szánra vonatkoztatható, és nagysága $z \approx(-2 \div 2) \mu m$, amely a főorsó irányú megmunkálások esetében jelent nem számottevő pontatlanságot.

A modál analízis a rezgési karakterisztika vizsgálatával foglalkozik és bármely fizikai rendszer sajátfrekvenciáinak a meghatározását teszi lehetővé [4]. Alapösszefüggése

$$
\underline{\underline{M}} \cdot \underline{\dot{q}}+\underline{\underline{K}} \cdot \underline{q}=\underline{f}
$$

alakú. A fenti (4) egyenletet átalakítva, a kapott összefüggés a

$$
\underline{\underline{M}}^{-1} \cdot \underline{\underline{K}}=\alpha^{2}=\lambda
$$

sajátértékfeladatra vezethető vissza [5]. 


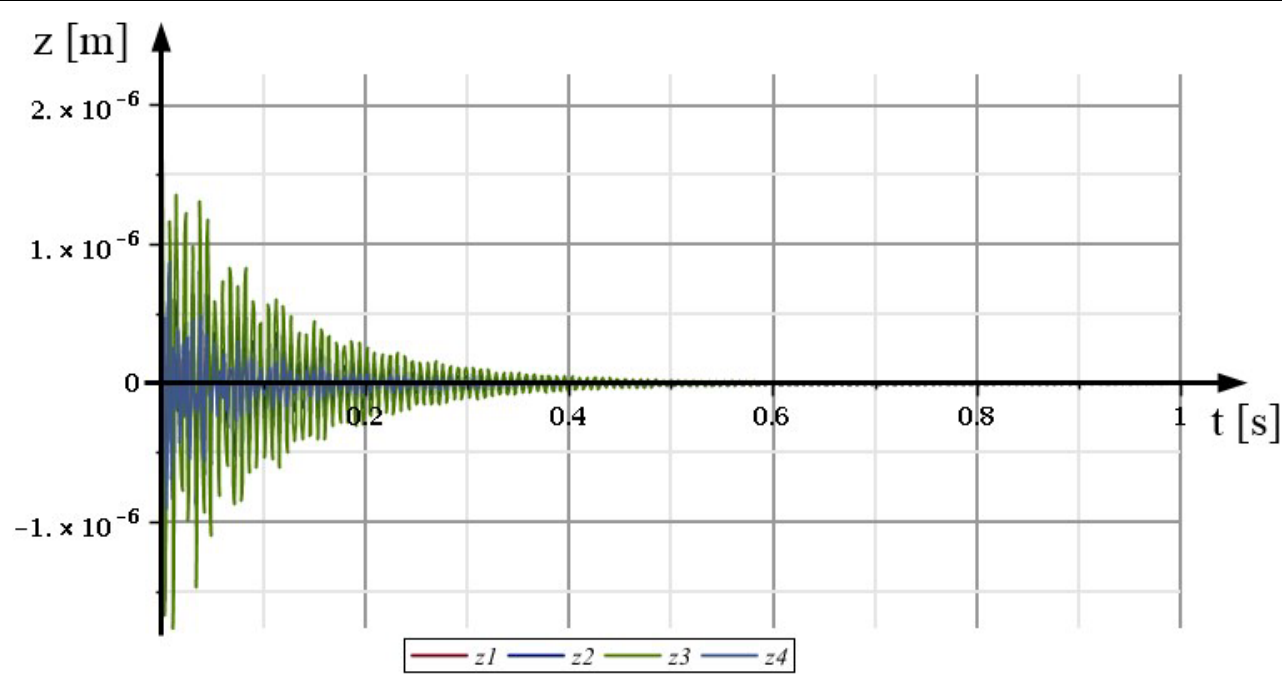

2. ábra. Amplitúdó-idö diagram - csillapitott esetben

Ezt egy alkalmas matematikai szoftver segítségével megoldva, a keresett sajátfrekvenciák a következök, a fenti nyolc szabadságfokú rezgéstani modellre alapozva:

\begin{tabular}{ccccc}
\hline módus & $\lambda\left[\frac{\mathrm{rad}^{2}}{\mathrm{~s}^{2}}\right]$ & $\alpha\left[\frac{\mathrm{rad}}{\mathrm{s}}\right]$ & $\mathrm{T}[\mathrm{s}]$ & $\mathrm{f}[\mathrm{Hz}]$ \\
\hline 1 & $4,553 \cdot 10^{5}$ & 674,74 & 0,0093 & 107,3882 \\
2 & $7,112 \cdot 10^{5}$ & 843,328 & 0,0075 & 134,2199 \\
3 & $1,011 \cdot 10^{6}$ & 1005,586 & 0,0062 & 160,0439 \\
4 & $1,932 \cdot 10^{6}$ & 1389,829 & 0,0045 & 221,1982 \\
5 & $3,955 \cdot 10^{6}$ & 1988,684 & 0,0032 & 316,5089 \\
6 & $5,662 \cdot 10^{6}$ & 2379,484 & 0,0026 & 378,7066 \\
7 & $1,153 \cdot 10^{7}$ & 3396,107 & 0,0019 & 540,5072 \\
8 & $1,716 \cdot 10^{7}$ & 4142,302 & 0,0015 & 659,2678 \\
\hline
\end{tabular}

3. ábra. A kapott eredmények összefoglalása

\section{4. Összefoglalás}

Jelen cikkben egy lehetséges módszert mutattunk be egy megmunkáló központ dinamikai merevségének (sajátfrekvenciáinak) analitikus meghatározására. A módszer rendkívül időigényes a nagy számítás-, és munkaigénye miatt több-szabadságfokú rendszereknél, azonban egyszerübb esetekben akár gyorsabb és egyszerübb is lehet más módszereknél. Az eredményeket tekintve közel azonos értékeket kaptunk, mint más - pl. a numerikus mechanika által is alkalmazott - eljárásokkal.

\section{Köszönetnyilvánítás}

A cikkben ismertetett kutató munka az EFOP-3.6.1-16-2016-00011 jelü „Fiatalodó és Megújuló Egyetem - Innovatív Tudásváros - a Miskolci Egyetem intelligens szakosodást szolgáló intézményi 
fejlesztése" projekt részeként - a Széchenyi 2020 keretében - az Európai Unió támogatásával, az Európai Szociális Alap társfinanszírozásával valósul meg.

\section{Irodalom}

[1] Kiss, R., Szilágyi, A.: Analysis of the dynamic behaviour of the CNC machine centre by FEM, DMS Journal, Miskolc, 2019. Február

[2] Kiss, R.: CNC megmunkáló központ dinamikai viselkedésének vizsgálata végeselemmódszerrel, Diplomaterv, Miskolc, 2019.

[3] Csernák, G., Stépán, G.: A müszaki rezgéstan alapjai. Egyetemi jegyzet, Budapest, BME, 2012.

[4] Dömötör, F.: Rezgésdiagnosztika I., Dunaújvárosi Főiskola, Dunaújváros, 2008.

[5] Pascal, M.: Parallelization of Design and Simulation: Virtual Machine Tools in Real Product Development. Doctoral Thesis, ETH Zürich, 2012. 